\title{
Perbedaan Pengaruh Penggunaan Model Pembelajaran Kooperatif Tipe Number Head Together (NHT) dan Team Games Tournament (TGT) Terhadap Prestasi Belajar Matematika Ditinjau dari Jenis Kelamin
}

\author{
Christiana Sri Wahyuni Kustiasih¹, Sunardi², Sri Haryati3 \\ annachris91@yahoo.co.id
}

Abstract: The purpose of this research is to find out (1) the difference of effect between the NHT, TGT, and Directive learning (DL) models on the mathematics learning achievement. (2) the difference of learning achievement on mathematics between boys and. (3) the interaction of effect between learning model and gender on mathematics learning achievement. This kind of research is a quantitative one which uses an experimental factorial design. The population of this research are all the $7^{\text {th }}$ grade - $1^{\text {st }}$ semester students of SMP 1 Sidoharjo, Sragen on the Academic Year Of 2015/2016. The sample is determined by taking 3 clsasses at random. The sampling technique uses the Cluster Random Sampling. The experimental group was treated by the NHT and TGT learning models. While the control group was subjected to the directive learning. For the teaching material is used the Algebraic design. The hypothesis testing uses the factorial design 3x2 with Two-Ways Analysis of Variance (Two Ways Anava) technique with different cells. Before, the trial test was conducted. Forth, for the balance testing was used the t-testing. For the reliability testing of the research instrument with internal consistency was used the Kuder Richardson (KR-20) formula, normality test used the lilliefors method, and the homogenity test used the Bartlet method. The result of the data analysis with significance level of 0.05 obtained: (1) FA $=3.641$ and Ftable $=3.07$, it mean FA > Ftable. The conclusion of HOA test was rejected and H1A was accepted, which means that there is a significant difference between the learning models to the mathematics achievement. (2) $F B=15.197$ and Ftable $=3.92$, it obtained FB $>$ Ftable. $H O B$ test was rejected and $H 1 B$ was accepted. It means that there is a significant difference between boys and girls to the mathematics achievement. (3) $F A B=4.353$, Ftable $=3.07$, obtained $F A B>F_{\text {table. }} H O A B$ was rejected and $H 1 A B$ was accepted, it means that there is a significant interaction of effect between gender and learning models to the mathematics achievement at the subject of Algebraic design.

Keywords: Cooperative Learning Model, Numbered Head Together (NHT), Team Games Tournament (TGT), Gender, Mathematics Learning Achievement.

\footnotetext{
${ }^{1}$ Alumni Magister Teknologi Pendidikan Universitas Sebelas Maret Surakarta

2 Dosen Universitas Sebelas Maret Surakarta

${ }^{3}$ Dosen Universitas Sebelas Maret Surakarta
} 


\section{PENDAHULUAN}

engajaran matematika di sekolah merupakan salah satu cara meningkatkan kualitas manusia dalam hal penguasaan berpikir secara logika. Belajar matematika mengantar manusia ke dalam pemikiran yang jelas, tepat dan teliti. Oleh karena itu, penguasaan matematika secara tuntas oleh peserta didik sangat diperlukan. Namun kenyataan bahwa prestasi belajar matematika masih lebih rendah bila dibandingkan dengan pelajaran yang lain.

Faktor penyebab rendahnya hasil ulangan matematika salah satunya adalah pembelajaran yang kurang bervariasi. Guru kurang dapat menciptakan suasana belajar yang menyenangkan, sehingga peserta didik menjadi mudah bosan dan kurang aktif dalam mengikuti pelajaran matematika. Hal ini terutama karena kurangnya pemahaman tentang berbagai model pembelajaran. Untuk itu perlu diupayakan agar prestasi belajar matematika meningkat, baik bagi peserta didik laki-laki maupun perempuan.

Salah satu upaya untuk mengatasi masalah tersebut, adalah dengan penerapan model pembelajaran yang bervariasi, Model pembelajaran kooperatif tipe Number Head Together (NHT) dan Team Games Tournament (TGT) dapat menjadi alternatif dalam mengurangi kejenuhan belajar matematika. Persamaan antara NHT dan TGT bahwa kedua model tersebut merupakan model pembelajaran kooperatif yang salah satu cirinya adalah bekerja dalam kelompok (Teamwork).

1. Untuk mengetahui apakah terdapat perbedaan pengaruh antara model pembelajaran NHT, TGT dan DL terhadap prestasi belajar matematika peserta didik klas VII semester I SMP Negeri 1 Sidoharjo, Sragen.

2. Untuk mengetahui apakah teradapat perbedaan prestasi belajar matematika antara jenis kelamin laki-laki dan perempuan peserta didik klas VII semester I SMP Negeri 1 Sidoharjo, Sragen.

3. Untuk mengetahui apakah terdapat interaksi pengaruh antara model pembelajaran dan jenis kelamin terhadap prestasi belajar peserta didik klas VII semester I SMP Negeri 1 Sidoharjo, Sragen.

\section{KAJIAN TEORI}

NHT atau model Penomoran Berpikir Bersama, menurut Jumanta Hamdayama (2014:175), "merupakan jenis pembelajaran kooperatif yang dirancang mempengaruhi pola interaksi siswa dan sebagai alternatif terhadap sumber struktur klas tradisional", di mana peserta didik dikelompokkan dengan diberi nomor. Teknik yang dikembangkan oleh Spencer Kagan ini memberikan kesempatan kepada peserta didik untuk saling membagikan ide-ide dan mempertimbangkan jawaban yang paling tepat. Selain itu, teknik ini juga mendorong peserta didik untuk meningkatkan semangat kerja sama mereka. Adapun ciri-ciri model pembelajaran tipe NHT menurut Madjid (2013) antara lain : a) Penomoran, b) Pengajuan pertanyaan, c) Berpikir bersama, dan d) Pemberian jawaban.

Kelebihan dari model pembelajaran tipe NHT menurut Hamdayama (2014) antara lain: a) melatih siswa untuk dapat bekerja sama dan menghargai pendapat orang lain, b) melatih siswa untuk bisa menjadi tutor sebaya, c) memupuk rasa kebersamaan, d) membuat siswa menjadi terbiasa dengan perbedaan. Kelemahan NHT adalah bahwa guru harus bisa memfasilitasi siswa karena siswa yang sudah terbiasa dengan cara DL akan sedikit kewalahan utamanya ketika ia harus berpikir untuk memberikan jawaban.

Model Pembelajaran tipe Teams Games Tournament (TGT) yang pada mulanya dikembangkan oleh David De Vries dan Keith Edwards ini menggabungkan suatu kelompok belajar dan kompetisi tim. Model ini dapat digunakan untuk mengembangkan pelajaran macam-macam fakta, konsep, dan keahlian yang luas. TGT menurut Slavin (2005:6) menggunakan presentasi guru dan pembentukan 
kelompok. Turnamen diadakan di akhir kegiatan, di mana siswa berkelompok berkontribusi mengumpulkan nilai (point) bagi dirinya maupun bagi kelompok.

Kegiatan tutor sebaya terlihat ketika peserta didik melaksanakan turnamen yaitu setelah masingmasing anggota kelompok membuat soal dan jawabannya, untuk selanjutnya saling mengajukan pertanyaan dan belajar bersama. Proses pembelajaran yang berlangsung dengan keaktifan dari peserta didik ini melatih peserta didik untuk bersosialisasi dengan orang lain. Hal ini meningkatkan kebaikan budi, kepekaan, dan toleransi.

Kelemahan model TGT bagi guru adalah bahwa guru harus menyusun kelompok dengan kemampuan heterogen dari segi akademis dan harus menyediakan waktu lebih guna mempersiapkan turnamen. Sementara bagi peserta didik yang kurang terbiasa dengan pembelajaran tutor sebaya, meskipun berkemampuan akademis tinggi akan sulit memberikan penjelasan kepada temannya.

Prestasi belajar menurut Hamalik (2001) bahwa, "Prestasi belajar adalah hasil yang diperoleh dari kegiatan belajar yaitu terjadinya tingkah laku dari tidak tahu menjadi tahu, dari tidak mengerti menjadi mengerti".

Hasil yang diperoleh dari belajar matematika dapat diketahui setelah dilakukan evaluasi. Masykur, Fatani, dan Halim (2008) mengemukakan bahwa, "Evaluasi tidak hanya dilakukan untuk menilai hasil akhir dari proses belajarnya tetapi juga menilai bagaimana proses mendapatkan hasil tersebut, sehingga proses berpikir matematikanya dapat terlihat secara jelas dan obyektif".

Jenis kelamin merupakan perbedaan berdasarkan struktur biologis. Laki-laki dan perempuan memiliki anatomi tubuh yang berbeda termasuk salah satunya adalah struktur otak.

Michael Guriaan dalam Masykur, Fatani, dan Halim (2008) menjelaskan bahwa "Perbedaan antara otak laki-laki dan perempuan terletak pada ukuran bagian-bagian otak, yaitu bagaimana bagian itu berhubungan dan bagaimana cara kerjanya. Perbedaan mendasar itu antara lain : 1) Perbedaan Spasial, 2) Perbedaan Verbal, 3) Perbedaan Bahan Kimia, dan 4) Memori"

Perbedaan tersebut tentu mempengaruhi pola tingkah laku, tingkat kecerdasan, perkembangan fisik maupun psikis, serta cara berpikir. Kelompok laki-laki akan cenderung menggunakan kemampuan spasial sementara perempuan akan cenderung menggunakan kemampuan verbalnya untuk menyelesaikan masalah.

\section{METODE PENELITIAN}

Penelitian dilakukan di SMP Negeri 1 Sidoharjo, Kabupaten Sragen. Waktu penelitian pada semester ke 1(satu) tahun pelajaran 2015/2016.

Jenis penelitian ini adalah penelitian kuantitatif menggunakan desain faktorial eksperimental, dengan populasi semua siswa-siswi SMP Negeri 1 Sidoharjo, Sragen klas VII semester ke 1(satu) tahun pelajaran 2015/2016 dan diambil tiga kelas sebagai sampel penelitian.

Teknik pengambilan sampel dengan Cluster random sampling. Teknik random sampling digunakan untuk memilih secara acak kelas yang akan dijadikan subyek penelitian. Teknik pengambilan data dalam penelitian ini menggunakan metode tes dan dokumenter. Metode tes digunakan untuk mengumpulkan data tentang prestasi belajar Matematika dan metode dokumenter digunakan untuk mengetahui keadaan awal populasi. Materi ajar mengambil pokok bahasan Bentuk Aljabar.

Langkah awal dilakukan uji coba tes. Teknik Uji keseimbangan menggunakan Uji-t dengan mengambil data nilai Ulangan Tengah Semester (UTS). Melalui uji keseimbangan diketahui bahwa antara kelompok eksperimen dan kelompok kontrol memiliki kemampuan yang sama/ seimbang. Pengujian reliabilitas instrumen penelitian dengan Internal Consistency menggunakan rumus Kuder 
Richardson (KR-20), uji normalitas yang menggunakan metode lilliefors, dan uji homogenitas menggunakan metode bartlet.

Uji hipotesis menggunakan rancangan desain faktorial 3x2 dengan teknik Analisis Varians Dua Jalan (Two Ways Anava) dengan sel tak sama. Selanjutnya jika terdapat interaksi maka akan dilakukan uji pasca ANAVA dengan uji Scheffe.

\section{HASIL PENELITIAN}

Sebelum data diolah dengan menggunakan Anava Dua Jalan, data hasil penelitian disajikan pada tabel seperti di bawah ini :

Tabel 1. Rangkuman Data Prestasi Belajar Matematika

\begin{tabular}{|c|c|c|c|c|}
\hline \multirow[t]{2}{*}{ Model Pembelajaran } & \multicolumn{3}{|c|}{ Jenis kelamin } & \multirow[t]{2}{*}{ TOTAL } \\
\hline & & LAKI-LAKI & PEREM PUAN & \\
\hline \multirow[t]{7}{*}{ NHT } & nij & 14 & 18 & 32 \\
\hline & $\sum x i j$ & 864 & 1360 & 2224 \\
\hline & $\overline{\bar{X}}$ & 61,71 & 75,56 & 69,50 \\
\hline & $\sum x^{2} i j$ & 54848 & 105408 & 160256 \\
\hline & SD & 10,84 & 12,49 & 13,55 \\
\hline & Nmax & 76 & 96 & 96 \\
\hline & Nmin & 44 & 48 & 44 \\
\hline \multirow[t]{7}{*}{ TGT } & nij & 14 & 18 & 32 \\
\hline & $\sum x i j$ & 1017 & 1296 & 2313 \\
\hline & $\bar{X}$ & 72,64 & 72,00 & 72,28 \\
\hline & $\sum x^{2} i j$ & 74673 & 95456 & 170129 \\
\hline & SD & 7,82 & 11,23 & 9,74 \\
\hline & Nmax & 84 & 92 & 92 \\
\hline & Nmin & 52 & 52 & 52 \\
\hline \multirow[t]{7}{*}{$\mathrm{DL}$} & nij & 14 & 18 & 32 \\
\hline & $\sum x i j$ & 800 & 1292 & 2092 \\
\hline & & 57,14 & 71,778 & 65,38 \\
\hline & $\sum x^{2} i j$ & 47872 & 95504 & 143376 \\
\hline & SD & 12,88 & 12,76 & 14,60 \\
\hline & Nmax & 88 & 96 & 96 \\
\hline & Nmin & 40 & 52 & 40 \\
\hline \multirow[t]{7}{*}{ TOTAL } & nij & 42 & 54 & 96 \\
\hline & $\sum x i j$ & 2520 & 3952 & 6472 \\
\hline & $\overline{\bar{X}}$ & 60 & 73,185 & 67,417 \\
\hline & $\sum x^{2} i j$ & 157920 & 297152 & 455072 \\
\hline & SD & 12,35 & 12,07 & 12,98 \\
\hline & Nmax & 88 & 96 & 96 \\
\hline & Nmin & 40 & 48 & 40 \\
\hline
\end{tabular}

\section{Uji Kesimbangan}

Sebelum eksperimen dilaksanakan, kelompok eksperimen dan kelompok kontrol diuji keseimbangan rata-ratanya. Diharapkan hasil yang diperoleh berasal dari perlakuan yang diberikan pada masing- 
masing kelompok bukan karena pengaruh lainnya. Teknik yang digunakan adalah mengunakan uji t dengan taraf signifikansi 0,05 .

Tabel 2. Rangkuman Hasil uji Keseimbangan

\begin{tabular}{cccc}
\hline Variabel & $\mathbf{t}_{\text {hitung }}$ & $\mathbf{t}_{\text {tabel }}$ & Kesimpulan \\
\hline Kontrol - Eksperi men 1 & $-1,3835$ & 1,960 & Seimbang \\
Kontrol - Eksperimen 2 & 0,1653 & 1,960 & Seimbang \\
Eksperimen 1 - Eksperimen 2 & 1,7705 & 1,960 & Seimbang \\
\hline
\end{tabular}

Tabel di atas menunjukkan hasil uji keseimbangan antara kelompok kontrol dan kelompok eksperimen yaitu bahwa thitung < tabel sehingga dapat disimpulkan bahwa ketiga kelas memiliki kemampuan yang seimbang.

\section{Uji Normalitas}

Uji normalitas digunakan untuk menguji apakah data yang diperoleh berdistribusi normal atau tidak. Penelitian ini menggunakan uji normalitas Lilliefors dengan taraf signifikansi 0,05.

Tabel 3. Rangkuman Hasil Uji Normalitas Data Penelitian

\begin{tabular}{lcccl}
\hline \multicolumn{1}{c}{ Vari abel } & $\mathrm{N}$ & Lmaks & $\mathrm{L}$ tabel & KESIM PULAN \\
\hline Total & 96 & 0,0834 & 0,0904 & Normal \\
NHT & 32 & 0,0913 & 0,1566 & Normal \\
TGT & 32 & 0,1523 & 0,1566 & Normal \\
DL & 32 & 0,1077 & 0,1566 & Normal \\
Laki- Laki & 42 & 0,0934 & 0,1367 & Normal \\
Perem puan & 54 & 0,0991 & 0,1206 & Normal
\end{tabular}

Dari tabel tersebut dapat dilihat bahwa Lnitung $<$ Ltabel sehingga dapat disimpulkan bahwa sebaran data dalam distribusi normal.

\section{Uji Homogenitas}

Uji homogenitas digunakan untuk menguji kesamaan varians antara dua kelompok yang dibandingkan. Dalam penelitian ini menggunakan uji Bartlett dengan taraf signifikansi 0,05.

Tabel 4. Rangkuman Hasil uji Homogenitas

\begin{tabular}{cccl}
\hline Variabel & $x^{2}$ hitung & $x^{2}$ tabel & Kesim pulan \\
\hline Model & 5,193 & 5,991 & Homogen \\
\hline Jenis Kelamin & 0,024 & 3,841 & Homogen \\
\hline
\end{tabular}

Berdasarkan analisis uji Bartlett diperoleh nilai $X^{2}$ hitung $<X^{2}$ tabel maka dapat disimpulkan bahwa variansi data penelitian homogen.

\section{Pengujian Hipotesis}

Pengujian hipotesis mengunakan analisis variansi dua jalan sel tak sama. Tujuan analisis veriansi dua jalan ini adalah untuk menguji signifikansi interaksi kedua variabel bebas terhadap veriabel terikat yaitu 
dengan melihat perbedaan efek baris, efek kolom, dan efek interaksi baris dan kolom terhadap variabel terikat.

Tabel 5. Hasil Uji Analisis Variansi Dua Jalan

\begin{tabular}{lcccccc}
\hline \multicolumn{1}{c}{ Sumber } & Jk & Dk & Rk & Fobs & $\boldsymbol{F}_{\text {tabel }}$ & Keputusan \\
\hline Model Pembelajaran (A) & 974,55 & 2 & 487,277 & 3,641 & 3,07 & Ditolak \\
Jenis Kelamin (B) & 2033,573 & 1 & 2033,573 & 15,197 & 3,92 & Ditolak \\
Interaksi (AB) & 1165,055 & 2 & 582,527 & 4,353 & 3,07 & Ditolak \\
Galat & 12043,341 & 90 & 133,815 & & & \\
Total & 16216,523 & 95 & & & & \\
\hline
\end{tabular}

Berdasarkan tabel di atas dengan taraf signifikan 0,05 dapat diinterpretasikan sebagai berikut:

1. Efek utama $A$ menghasilkan $F_{A}=3,641, F_{\text {tabel }}=3,07$ diperoleh $F_{A}>F_{\text {tabel. }}$ Sehingga keputusan uji $\mathrm{H}_{0 \mathrm{~A}}$ ditolak dan $\mathrm{H}_{1 \mathrm{~A}}$ diterima yang artinya terdapat perbedaan pengaruh yang signifikan antara model pembelajaran terhadap prestasi belajar matematika. Dengan kata lain bahwa kedua model pembelajaran memberikan pengaruh yang berbeda terhadap prestasi belajar matematika pada pokok bahasan bentuk aljabar.

2. Efek utama $B$ menghasilkan $F_{B}=15,197$ dan $F_{\text {tabel }}=3,92$, diperoleh $F_{B}>F_{\text {tabel }}$. Keputusan uji $H_{0 B}$ ditolak dan $\mathrm{H}_{1 \mathrm{~B}}$ diterima, artinya terdapat perbedaan pengaruh yang signifikan antara jenis kelamin siswa terhadap prestasi belajar matematika. Hal ini berarti jenis kelamin memberikan pengaruh yang berbeda terhadap prestasi belajar matematika siswa pada pokok bahasan Bentuk Aljabar.

3. Interaksi $A B$ menghasilkan $F_{A B}=4,353, \quad F_{\text {tabel }}=3,07$, diperoleh $F_{A B}>F_{\text {tabel }}$. Keputusan uji $H_{0 A B}$ ditolak dan $\mathrm{H}_{1 \mathrm{AB}}$ diterima, artinya terdapat interaksi pengaruh yang signifikan antara model pembelajaran dan jenis kelamin terhadap prestasi belajar matematika siswa pada pokok bahasan Bentuk Aljabar. Karena keputusan uji $\mathrm{H}_{\mathrm{OA}}, \mathrm{H}_{\mathrm{OB}}$, maupun $\mathrm{H}_{\mathrm{OAB}}$ ditolak maka perlu dilakukan uji lanjut pasca anava. Bentuk interaksinya disajikan dalam tabel berikut ini:

Tabel 6. Rangkuman hasil Uji Lanjut Pasca ANAVA

\begin{tabular}{|c|c|c|c|}
\hline $\mathrm{H}_{0}$ & $F_{\text {hitung }}$ & $F_{0,05 ; 2 ; 90}$ & Kep. Uji \\
\hline 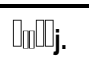 & 1,62 & 6,14 & Diterima \\
\hline 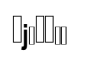 & 2,08 & 6,14 & Diterima \\
\hline 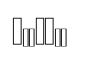 & 7,39 & 6,14 & Ditolak \\
\hline $\mathrm{H}_{0}$ & $F_{\text {hitung }}$ & $F_{0,05 ; 1 ; 90}$ & Kep. Uji \\
\hline 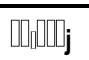 & 15,20 & 3,97 & Ditolak \\
\hline $\mathrm{H}_{0}$ & $F_{\text {hitung }}$ & $F_{0,05 ; 6 ; 90}$ & Kep Uji \\
\hline 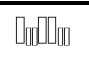 & 11,275 & 13,5 & Diterima \\
\hline 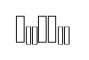 & 0,024 & 13,5 & Diterima \\
\hline 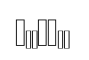 & 12,605 & 13,5 & Diterima \\
\hline $\mathrm{H}_{0}$ & $F_{\text {hitung }}$ & $F_{0,05 ; 6 ; 90}$ & Kep. Uji \\
\hline 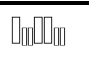 & 6,248 & 13,5 & Diterima \\
\hline
\end{tabular}




\begin{tabular}{|c|c|c|c|}
\hline 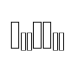 & 1,093 & 13,5 & Diterima \\
\hline 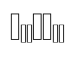 & 12,568 & 13,5 & Diterima \\
\hline प्राप्याओ & 0,850 & 13,5 & Diterima \\
\hline पnol|lin & 1,229 & 13,5 & Diterima \\
\hline 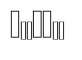 & 0,003 & 13,5 & Diterima \\
\hline
\end{tabular}
berikut:

Dari tabel rangkuman hasil uji lanjut pasca anava tersebut dapat diinterpretasikan sebagai

1. Tidak terdapat perbedaan rerata yang signifikan antara prestasi belajar matematika pada siswa dengan model NHT dan prestasi belajar matematika pada siswa yang menggunakan model TGT.

2. Tidak terdapat perbedaan rerata yang signifikan antara prestasi belajar matematika pada siswa dengan model TGT dan prestasi belajar matematika pada siswa yang menggunakan model DL

3. Terdapat perbedaan rerata yang signifikan antara prestasi belajar matematika pada siswa dengan model $N H T$ dan prestasi belajar matematika pada siswa yang menggunakan model DL

4. Terdapat perbedaan rerata yang signifikan antara prestasi belajar matematika pada siswa lakilaki dan prestasi belajar matematika pada siswa perempuan

5. Tidak terdapat perbedaan rerata yang signifikan antara prestasi belajar matematika pada siswa laki-laki dengan model NHT dan prestasi belajar matematika pada siswa perempuan yang menggunakan model NHT.

6. Tidak terdapat perbedaan rerata yang signifikan antara prestasi belajar matematika pada siswa laki-laki dengan model TGT dan prestasi belajar matematika pada siswa perempuan yang menggunakan model TGT.

7. Tidak terdapat perbedaan rerata yang signifikan antara prestasi belajar matematika pada siswa laki-laki dengan model DL dan prestasi belajar matematika pada siswa perempuan yang menggunakan model DL

8. Tidak terdapat perbedaan rerata yang signifikan antara prestasi belajar matematika pada siswa laki-laki dengan model NHT dan prestasi belajar matematika pada siswa laki-laki yang menggunakan model TGT.

9. Tidak terdapat perbedaan rerata yang signifikan antara prestasi belajar matematika pada siswa laki-laki dengan model TGT dan prestasi belajar matematika pada siswa laki-laki yang menggunakan model DL.

10. Tidak terdapat perbedaan rerata yang signifikan antara prestasi belajar matematika pada siswa laki-laki dengan model $N H T$ dan prestasi belajar matematika pada siswa laki-laki yang menggunakan model DL

11. Tidak terdapat perbedaan rerata yang signifikan antara prestasi belajar matematika pada siswa perempuan dengan model NHT dan prestasi belajar matematika pada siswa perempuan yang menggunakan model TGT.

12. Tidak terdapat perbedaan rerata yang signifikan antara prestasi belajar matematika pada siswa perempuan dengan model TGT dan prestasi belajar matematika pada siswa perempuan yang menggunakan model DL. 
13. Tidak terdapat perbedaan rerata yang signifikan antara prestasi belajar matematika pada siswa perempuan dengan model NHT dan prestasi belajar matematika pada siswa perempuan yang menggunakan model DL

\section{PEMBAHASAN}

Pembahasan hasil analisis dan pengujian hipotesis tersebut dapat diuraikan sebagai berikut:

\section{Perbedaan Pengaruh antara Model Pembelajaran Tipe NHT, TGT, dan Directive Learning (DL) terhadap Prestasi Belajar}

Model Pembelajaran $(A)$ dengan taraf siginifikansi 5\% menghasilkan $F_{o b s}$ sebesar 3,641 yang lebih besar dari $F_{\text {tabel }}$ yaitu 3,07. Dengan demikian $\mathrm{H}_{0 \mathrm{~A}}$ ditolak dan $\mathrm{H}_{1 \mathrm{~A}}$ diterima yang artinya terdapat pengaruh antara model NHT dan TGT terhadap prestasi belajar matematika siswa. Dari analisis deskriptif menunjukkan nilai rata-rata prestasi belajar siswa yang menggunakan model TGT sebesar 72,28 lebih tinggi bila dibandingkan dengan prestasi belajar siswa yang mengunakan model NHT yaitu sebesar 69,50.

Setelah dilakukan uji lanjut pasca anava pada komparasi antar baris diperoleh hasil keputusan bahwa tidak terdapat perbedaan rerata yang signifikan antara prestasi belajar matematika pada siswa dengan model NHT dan prestasi belajar matematika pada siswa yang menggunakan model TGT. Artinya model pembelajaran baik NHT maupun TGT tidak memberikan pengaruh signifikan terhadap prestasi belajar matematika.

Demikian juga tidak terdapat perbedaan rerata yang signifikan antara prestasi belajar matematika pada siswa dengan model TGT dan prestasi belajar matematika pada siswa yang menggunakan model DL. Artinya model pembelajaran baik TGT maupun DL tidak memberikan pengaruh yang signifikan terhadap prestasi belajar matematika.

Sementara antara prestasi belajar matematika pada siswa dengan model NHT dan prestasi belajar matematika pada siswa yang menggunakan model $\mathrm{DL}$ terdapat perbedaan rerata yang signifikan. Model pembelajaran NHT lebih memberikan pengaruh positif terhadap peningkatan prestasi belajar matematika dibandingkan model DL.

\section{Pengaruh Jenis Kelamin Terhadap Prestasi Belajar}

Jenis kelamin $(B)$ dengan taraf siginifikansi $5 \%$ menghasilkan $F_{\text {obs }}$ sebesar 15,197 yang lebih besar dari $F_{\text {tabel }}$ yaitu 3,92. Dengan demikian $\mathrm{H}_{0 \mathrm{~B}}$ ditolak dan $\mathrm{H}_{1 \mathrm{~B}}$ diterima, itu artinya terdapat pengaruh antara siswa laki-laki dan perempuan terhadap prestasi belajar matematika. Dari analisis deskriptif menunjukkan nilai rata-rata prestasi belajar siswa perempuan sebesar 73,11 . Hasil ini lebih tinggi bila dibandingkan dengan prestasi belajar siswa laki-laki yaitu sebesar 63,83. Keadaan tersebut diperkuat oleh hasil setelah dilakukan uji lanjut pasca anava. Pada komparasi antar kolom diperoleh $F_{\text {hitung }} 15,20$ yang lebih besar dari $F_{0,05 ; 1 ; 90}$ yaitu 3,97. Dengan demikian hasil keputusan uji $\mathrm{H}_{0 \mathrm{~B}}$ ditolak dan $\mathrm{H}_{1 \mathrm{~B}}$ diterima, artinya bahwa terdapat perbedaan rerata yang signifikan antara prestasi belajar matematika pada siswa laki-laki dan prestasi belajar matematika siswa perempuan. Ini menunjukkan bahwa prestasi belajar matematika siswa perempuan lebih baik dibandingkan dengan prestasi belajar matematika siswa laki-laki.

Hal tersebut didukung oleh teori yang dikemukakan Michael Guriaan dalam Masykur, Fatani, dan Halim (2008) bahwa pusat memori pada otak perempuan lebih besar ketimbang otak laki-laki, sehingga laki-laki lebih mudah lupa dan perempuan lebih bisa mengingat semuanya secara detail. 
Sama halnya dengan hasil penelitian yang dilakukan Nuyami (2014) dalam jurnalnya , antara lain disebutkan bahwa terdapat perbedaan self-efficacy siswa laki-laki dan kelompok siswa perempuan.

\section{Interaksi Pengaruh antara Model Pembelajaran dan Jenis Kelamin Terhadap Prestasi Belajar}

Interaksi antara Model pembelajaran dan jenis kelamin dengan taraf signifikansi $5 \%$, menunjukkan $F_{A B}=4,353, F_{\text {tabel }}=3,07$, diperoleh $F_{A B}>F_{\text {tabel }}$. Keputusan uji $\mathrm{H}_{0 A B}$ ditolak dan $\mathrm{H}_{1 A B}$ diterima, artinya terdapat interaksi pengaruh yang signifikan antara model pembelajaran dan jenis kelamin terhadap prestasi belajar matematika.

Setelah dilakukan uji lanjut pasca anava berdasarkan komparasi ganda antar sel pada baris yang sama diperoleh hasil bahwa tidak terdapat perbedaan rerata yang signifikan antara prestasi belajar matematika pada siswa laki-laki dengan model NHT dan prestasi belajar matematika pada siswa perempuan yang menggunakan model NHT. Artinya model pembelajaran NHT tidak memberikan pengaruh positif, baik pada siswa laki-laki maupun siswa perempuan.

Demikian juga halnya tidak terdapat perbedaan rerata yang signifikan antara prestasi belajar matematika pada siswa laki-laki dengan model TGT dan prestasi belajar matematika pada siswa perempuan yang menggunakan model TGT. Artinya bahwa model pembelajaran TGT tidak memberikan pengaruh positif baik pada siswa laki-laki maupun siswa perempuan.

Hal tersebut juga terjadi pada model pembelajaran DL yang hasilnya pada penelitian ini tidak terdapat perbedaan rerata yang signifikan antara prestasi belajar matematika pada siswa laki-laki dengan model $\mathrm{DL}$ dan prestasi belajar matematika pada siswa perempuan yang menggunakan model DL. Artinya bahwa model pembelajaran DL tidak memberikan pengaruh positif, baik pada siswa laki-laki maupun siswa perempuan.

Uji lanjut pasca anava berdasarkan komparasi ganda antar sel pada kolom yang sama menunjukkan bahwa (1) tidak terdapat perbedaan rerata yang signifikan antara prestasi belajar matematika pada siswa laki-laki dengan model NHT dan prestasi belajar matematika pada siswa lakilaki yang menggunakan model TGT. (2) Tidak terdapat perbedaan rerata yang signifikan antara prestasi belajar matematika pada siswa laki-laki dengan model TGT dan prestasi belajar matematika pada siswa laki-laki yang menggunakan model DL. (3) Tidak terdapat perbedaan rerata yang signifikan antara prestasi belajar matematika pada siswa laki-laki dengan model NHT dan prestasi belajar matematika pada siswa laki-laki yang menggunakan model DL. Itu berarti bahwa model pembelajaran NHT, TGT, maupun DL tidak mempengaruhi prestasi belajar matematika siswa laki-laki.

Penelitian ini juga memperoleh hasil bahwa (1) tidak terdapat perbedaan rerata yang signifikan antara prestasi belajar matematika pada siswa perempuan dengan model NHT dan prestasi belajar matematika pada siswa perempuan yang menggunakan model TGT. (2) Tidak terdapat perbedaan rerata yang signifikan antara prestasi belajar matematika pada siswa perempuan dengan model TGT dan prestasi belajar matematika pada siswa perempuan yang menggunakan model DL. (3) Tidak terdapat perbedaan rerata yang signifikan antara prestasi belajar matematika pada siswa perempuan dengan model NHT dan prestasi belajar matematika pada siswa perempuan yang menggunakan model DL. Itu berarti bahwa model pembelajaran NHT, TGT, maupun DL tidak mempengaruhi prestasi belajar matematika siswa perempuan.

\section{SIMPULAN}

Berdasarkan hasil analisis data dan pembahasan hasil penelitian dapat disimpulkan bahwa:

1. Terdapat perbedaan pengaruh yang signifikan antara model pembelajaran NHT, TGT, dan DL terhadap prestasi belajar matematika, artinya kedua model pembelajaran memberikan pengaruh 
yang berbeda terhadap prestasi belajar matematika peserta didik klas VII SMP Negeri 1 Sidoharjo, Sragen tahun pelajaran 2015/2016, pada pokok bahasan bentuk aljabar. Dari analisis deskriptif menunjukkan bahwa prestasi belajar siswa yang dikenai model pembelajaran TGT lebih baik dibandingkan siswa yang dikenai model pembelajaran NHT

2. Terdapat perbedaan prestasi belajar matematika antara jenis kelamin laki-laki dan perempuan. Hal ini berarti jenis kelamin memberikan pengaruh yang berbeda terhadap prestasi belajar matematika siswa pada pokok bahasan Bentuk Aljabar. Dari analisis deskriptif menunjukkan prestasi belajar siswa perempuan lebih tinggi bila dibandingkan dengan prestasi belajar siswa laki-laki. Keadaan tersebut diperkuat oleh hasil setelah dilakukan uji lanjut pasca anava bahwa terdapat perbedaan rerata yang signifikan antara prestasi belajar matematika pada siswa laki-laki dan prestasi belajar matematika siswa perempuan. Ini menunjukkan bahwa prestasi belajar matematika siswa perempuan lebih baik dibandingkan dengan prestasi belajar matematika siswa laki-laki.

3. Terdapat interaksi yang signifikan antara model pembelajaran dan jenis kelamin terhadap prestasi belajar matematika siswa pada pokok bahasan Bentuk Aljabar.

Bentuk interaksi antara model pembelajaran dengan jenis kelamin antara lain seperti berikut:

a. Terdapat perbedaan rerata yang signifikan antara prestasi belajar matematika pada siswa laki-laki dan prestasi belajar matematika pada siswa perempuan

b. Tidak terdapat perbedaan rerata yang signifikan antara prestasi belajar matematika pada siswa lakilaki dengan model NHT dan prestasi belajar matematika pada siswa perempuan yang menggunakan model NHT.

c. Tidak terdapat perbedaan rerata yang signifikan antara prestasi belajar matematika pada siswa lakilaki dengan model TGT dan prestasi belajar matematika pada siswa perempuan yang menggunakan model TGT.

d. Tidak terdapat perbedaan rerata yang signifikan antara prestasi belajar matematika pada siswa lakilaki dengan model DL dan prestasi belajar matematika pada siswa perempuan yang menggunakan model DL

e. Tidak terdapat perbedaan rerata yang signifikan antara prestasi belajar matematika pada siswa lakilaki dengan model NHT dan prestasi belajar matematika pada siswa laki-laki yang menggunakan model TGT.

f. Tidak terdapat perbedaan rerata yang signifikan antara prestasi belajar matematika pada siswa lakilaki dengan model TGT dan prestasi belajar matematika pada siswalaki-laki yang menggunakan model DL.

g. Tidak terdapat perbedaan rerata yang signifikan antara prestasi belajar matematika pada siswa lakilaki dengan model NHT dan prestasi belajar matematika pada siswa laki-laki yang menggunakan model DL

h. Tidak terdapat perbedaan rerata yang signifikan antara prestasi belajar matematika pada siswa perempuan dengan model $N H T$ dan prestasi belajar matematika pada siswa perempuan yang menggunakan model TGT.

i. Tidak terdapat perbedaan rerata yang signifikan antara prestasi belajar matematika pada siswa perempuan dengan model TGT dan prestasi belajar matematika pada siswa perempuan yang menggunakan model DL.

j. Tidak terdapat perbedaan rerata yang signifikan antara prestasi belajar matematika pada siswa perempuan dengan model NHT dan prestasi belajar matematika pada siswa perempuan yang menggunakan model DL 


\section{SARAN-SARAN}

Berdasarkan hasil penelitian dan pembahasan hasil penelitian maka peneliti memberikan beberapa saran sebagai berikut:

Untuk guru :

Hendaknya guru SMP Negeri 1 Sidoharjo, Sragen termotivasi untuk menerapkan model pembelajaran inovatif agar proses pembelajaran mampu mengoptimalkan prestasi belajar matematika. Alternatif model pembelajaran inovatif yang dapat diterapkan untuk mengoptimalkan prestasi belajar matematika adalah TGT dan NHT. Metode pembelajaran kooperatif tipe TGT dan metode pembelajaran kooperatif tipe NHT efektif karena itu disarankan agar menerapkanya dalam pembelajaran matematika pada materi yang lain.

Dalam memilih model pembelajaran, hendaknya lebih memperhatikan karakteristik siswa dalam suatu kelas diantaranya adalah jenis kelamin. Hal ini dimaksudkan agar setiap siswa dapat terlibat aktif dalam mengkonstruksi pemahamannya terhadap suatu konsep yang sedang dipelajari. Selain itu disarankan agar dalam proses belajar mengajar matematika perlu memperhatikan faktor-faktor lain yang mempengaruhi prestasi belajar matematika

Untuk siswa :

Pembelajaran teman sebaya menjadi alternatif siswa untuk belajar lebih efektif. Disarankan agar siswa membiasakan diri melakukan pembelajaran kooperatif dengan kerja kelompok untuk hasil prestasi yang lebih baik..

Untuk Sekolah :

Sekolah dalam peningkatan keprofesionalan hendaknya memfasilitasi para guru dengan cara mengadakan atau mengikutsertakan guru dalam diklat, dan atau pelatihan; Menyediakan sarana dan prasarana yang dibutuhkan oleh guru untuk menerapkan model-model pembelajaran yang berbeda; Memberikan motivasi kepada guru agar dapat menerapkan model pembelajaran yang bervariasi untuk meningkatkan minat, motivasi, kemandirian serta prestasi belajar siswa.

\section{REFERENSI}

Madjid, A. (2013). Strategi Pembelajaran”. Bandung. PT Remaja Rosdakarya

Hamdayama, J. (2014). Model dan Metode Pembelajaran Kreatif dan Berkarakter. Bogor: Ghalia Indonesia

Masykur, M. A., Fathani, \& Halim, A. (2008). Mathematical Intelligence: Cara Cerdas Melatih Otak dan Menanggulangi Kesulitan Belajar. Yogyakarta. Ar-Ruzz Media

Nuyami, M. S, Suastra I.W, Sadia, I.W. (2014). Pengaruh Model Pembelajaran Kooperatif Tipe ThinkPair-Share Terhadap Self-Efficacy Siswa SMP Ditinjau Dari Gender. Jurnal Pendidikan Indonesia, 4.

Hamalik, O. (2011). Proses Belajar Mengajar. Jakarta: Bumi Aksara.

Slavin, Robert E. (2005). Cooperative Learning: Theory, Research, and Practice. USA: A Simon \& Schuster Company. 